British Standards Institution and other bodies ; and further restrictive legislation in various directions would appear to be not unlikely. The problem of the measurement of noise, or rather of its 'equivalent loudness', is finding generally accepted solution both in Great Britain and abroad. The standard of comparison is a reference tone of 1,000 cycles per second with a specified arbitrary 'zero' of intensity. If the reference tone is increased in successive decibel steps of energy above the zero, the resulting changes of loudness are expressed in numerically identical steps on a scale of phons. The equivalent loudnesses of other sounds and noises are evaluated by aural matching against the reference tone when suitably adjusted. Other features to which Dr. Hughes refers in his informative article are the abatement of both air-borne sounds and impact noises and vibrations in buildings, impulse noises, and commercially available noise-measuring instruments.

\section{Wonders of Tinplate}

AN interesting film dealing with tinplate and canning, produced in France under the title "Magie du Fer-Blanc", was shown for the first time in England on December 2 at the Polytechnic Extension, Little Tichfield Street, London, W.1. The display took place under the auspices of the International Tin Research and Development Council, and Sir John Campbell, chairman of the Internation Tin Committee, introduced to the audience M. Peissi, director of l'Office Technique pour l'Utilisation de l'Acier, by whom the film had been produced. Various phases in the production of tinplate, the fabrication of containers and the canning of food were depicted. At present the film has French subtitles, but we understand that it is probable that an English accompaniment will be arranged and the film exhibited publicly in Great Britain.

\section{Meat Inspection in South America}

THE fourteenth Benjamin Ward Richardson lecture, founded in 1922 by the Model Abattoir Society (dissolved in 1935), was delivered in the rooms of the Royal Sanitary Institute, which has taken over the management of the Richardson Trust, on November 12, by Dr. M. T. Morgan of the Ministry of Health, on the system of health inspection of meat and meat products destined for export in the great abattoirs of South America. In accordance with instructions from his Department, Dr. Morgan recently visited the large factory abattoirs in the Argentine, Uruguay and Brazil which serve for the preparation of meat and meat products destined for export overseas and for local consumption. The products range from the finest quality chilled beef destined for the English market down to every variety of by-product from agricultural fertilisers to buttons for clothes. The finest quality meat is produced in the Argentine, and a slightly inferior quality in Uruguay. The system of inspection of meat and meat products is the same in all three countries, but is most highly developed in the Argentine, where it is a special branch of the State service of inspection of livestock and is not attached to the public health service as in Great Britain. A most efficiont inspoction of the animals is mude both before and after death. Wholo carcasses or sides or portions or viscera aro rejected on the slightest grounds of a suspicion that they are unhealthy or unsuitable for human consumption. In conclusion, Dr. Morgan states that in all three countries he was struck by the extraordinarily high standard of the service of inspection and the extreme cleanliness and efficiency in every department of the enormous factories.

\section{Britain in the Dark Ages}

A MAP of Britain in the Dark Ages (A.D. 410 to 871 ) is the third of the period maps to be published by the Ordnance Survey. The south sheet covering England, Wales and part of southern Scotland has now appeared (Southampton: Ordnance Survey. Cloth mounted. 5s. Paper, flat and unmounted. 2s. 6d.). The scale is $1: 1,000,000$ and the map is contoured and layer coloured. No attempt has been made at the almost impossible task of restoring the ancient coast line, but the forest covering is shown, and is the same as that on the map of Roman Britain. The entries on the map have been derived from both archæological and historical sources, and an attempt has been made to represent both the Celtic and Saxon aspects of the period. Different characters are used for place names of the two origins. Latin names, constantly used in documents of the period, are also differentiated. Roman roads, with one exception are omitted, since their use was uncertain. Churches, crosses, battle-sites, villages and other dwellings, and burial places are shown, and in the introductory pamphlet that goes with the map there are small maps showing respectively place names ending in -ing and the distribution of cemeteries. There is a complete index of ancient names with modern equivalents. The map is a beautiful example of cartography and shows a wide range of historical research without any suggestion of crowding of names or symbols.

\section{The Present Age}

WE have received the first two numbers of the Present Age, a new monthly journal edited and published by Dr. W. J. Stein, 144 Harborough Road, London, S.W.16 (2s, a month). The editor, in a covering circular, points out that modern life has created such a high degree of specialisation that it has become almost impossible to have cognisance of more than one sphere of knowledge or activity. The Present Age is designed to relate different fields of knowledge by the publication of articles apparently independent, but showing their true interrelationships. The January issue (1, No. 2) contains, among others, historical articles on "King Arthur", "Christmas through the Ages", and "Eurythmy in Ancient Greece", the last-named with four excellent plates of Nereids from figures in the Nereid Room of the British Museum. Science is represented by articles on "Alterations in the Earth's Surface", and "The 